JASa (Jurnal Akuntansi, Audit dan Sistem Informasi Akuntansi)

Vol. 4 No. 3/ December 2020

ISSN 2550-0732 print / ISSN 2655-8319 online

\title{
APPLICATION OF PSAK 109 IN ORGANIZATION OF ZAKAT MANAGERS (OPZ) IN SRAGEN DISTRICT (BAZNAS, LAZISNU, LAZISMU, AND LAZKU)
}

\author{
Jelita Mustika Sari ${ }^{1 *}$, Kartika Hendra Titisari ${ }^{2}$, Siti Nurlaela ${ }^{3}$ \\ Batik Islamic University, Indonesia. \\ jelitamustikasari@gmail.com
}

\begin{abstract}
This study aims to determine and analyze how the application of zakat and infaq / alms accounting in zakat management organizations in Sragen regency. This type of research is qualitative research. The population and sample used are zakat management organizations in Sragen district, by taking a sample using purposive sampling technique and obtained 4 zakat management organizations with comparative descriptive analysis. The results of this study indicate that not all zakat management organizations in Sragen regency have applied zakat and infaq / alms accounting in accordance with PSAK 109. LAZISNU and LAZISMU have applied but for LAZISNU it is not yet complete because reports on changes in assets under management and notes on financial statements are not made. While BAZNAS and LAZKU have not made financial reports, they only present reports on receipt and distribution of funds.
\end{abstract}

Keywords: PSAK 109; Alms; Infaq/ Alms; Financial Statements

\section{INTRODUCTION}

In Indonesia regulations governing the management of zakat, infaq and alms funds are contained in Law of the Republic of Indonesia Number 23 of 2013 and PP Number 14 of 2014 concerning the implementation of Law No. 23 of 2013. In addition to the two regulations on 6 October 2010 IAI issued a Statement of Financial Accounting Standards (PSAK) 109. PSAK 109 regulates how accounting treatment for zakat and donation / alms. PSAK 109 is prepared and issued for the purpose of uniforming financial reports prepared by zakat management organizations. However, in reality there are still a number of zakat management organizations that have not yet provided accounting treatment for zakat and donation / charity as in PSAK 109.

Seen from previous research on the application of PSAK 109. As stated by Budiarti et.al., (2014) BAZNAS Kota Yogyakarta has not yet applied the accounting records for zakat, Infaq / shadaqah as in PSAK 109. Pertiwi Research et.al., (2015) states that the report made by LAZISMU Malang Regency does not refer to PSAK 109 because it only reports monthly income and expenditure. Research Saputro et.al., (2018) shows that in the recognition, reduction, presentation and disclosure of LAZIS Sabilillah Malang has not applied PSAK 109.

This study is based on differences in results from previous studies. According to Kristin \& Umah (2011) the LAZ DPU DT Semarang financial report is not in accordance with PSAK 109. Pujianto \& Asrori (2015) found that amil attitude had no impact on Amil's interest in zakat and infaq / alms accounting practices in accordance with PSAK 109, and norms Subjective amil has an impact on the practice of accounting for zakat and donation / alms in accordance with PSAK 109. Pertiwi et al., (2015) found that financial LAZISMU statements in Malang Regency were not fully in accordance with PSAK 109, and Shahnaz (2015) found 
JASa (Jurnal Akuntansi, Audit dan Sistem Informasi Akuntansi)

Vol. 4 No. 3/ December 2020

ISSN 2550-0732 print / ISSN 2655-8319 online

that BAZNAS of North Sulawesi Province had not made financial reports in accordance with PSAK 109. Angraeni et.al., (2016) also found that BAZNAS of Bitung City had not recorded financial reports like those in PSAK 109, and Harianto (2016) expressed the same opinion that the financial statements of Baitul Mal Aceh were not in accordance with PSAK 109. Arief et.al ., (2017) stated that Manado City BAZNAS in the preparation of the report has not applied PSAK No. 109. Ritonga (2017) said that North Sumatra BAZNAS has not implemented the use of PSAK No. 109. Budiarti et al, (2017) also found that the city of Yogyakarta in writing BAZNAS financial statements are still not fully in accordance with SFAS 109. Saputro et al, (2018) explained that the preparation of financial statements LAZIS Sabilillah Malang not fully in accordance with PSAK 109. Mayangsari (2019) found that the application of zakat accounting in $\mathrm{BMH}$ Bondowoso Regency was not in accordance with PSAK 109.

This is different from Hidayat et.al., (2018) said that LAZNAS Rumah Yatim Arrohman had fully implemented the use of PSAK 109 in presents financial statements. Nugraha (2018) stated that the implementation of zakat accounting at LAZ YDSF Jember was in accordance with PSAK 109 and the recording of financial statements in accordance with PSAK 101. Marhaini \& Irwan (2018) said that the BAZNAS of NTB Province had made financial reports in accordance with PSAK 109, and Latief (2019) stated that the financial reporting conducted by BAZNAS North Sulawesi through the SIMBA BAZNAS application was in accordance with PSAK 109.

Sarea (2013) said that if the amil zakat institution in preparing its financial statements was prepared in accordance with zakat accounting standards as in AAOIFI FAS No. 9, the report presented is more transparent and can increase donor trust. Beik (2015) explains that in order to achieve international standardization of the zakat system it is necessary to expand the number of countries involved in the discussion of the principles of zakat, the IFSB can be optimized to facilitate cooperation on the standardization of the zakat system globally and must be widely communicated especially members of the OIC forum so as to create zakat accounting standards are the same globally. Ascarya (2014) states that zakat is an instrument of Islamic pillars with various aspects ranging from faith, economics, and social. So it is unfortunate when the accounting is not recorded properly.

Hamat (2014) found the
importance of sustainable zakat accounting for zakat institutions in Malaysia, such as developing zakat accounting for assets based on the qiyas method, this as an answer in meeting the demands and conditions of the zakat institutions at that time. Hamid \& Hamid (2019) said that with good reporting also increases the visibility, accountability and trust of muzakki in zakat institutions. Bremer (2013) said that there must be greater recognition of zakat and there must be a systematic effort to develop it. Hamat, et.al., (2017) said that the method of recording zakat accounting specifically from the receipt of shares is very important, because there are differences in accounting treatment for shares traded and those that are not. Bashir \& Ali (2012) said that good zakat management, especially in the recording and disbursement of zakat funds, had a positive impact on the progress of zakat institutions in Brunei Darussalam.

Doktoralina \& Bahari (2018) states that establishing AISoZ (Accounting Information System of Zakat) in reporting is an alternative to increasing the amount of zakat funds collected. Pamuncak et.al., 
JASa (Jurnal Akuntansi, Audit dan Sistem Informasi Akuntansi)

Vol. 4 No. 3/ December 2020

ISSN 2550-0732 print / ISSN 2655-8319 online

(2018) said that there are some conformity of characteristics between zakat institutions and umkm. In IFRS there are 35 standards governing umkm accounting, 11 of which can be applied to zakat institutions. Ahmed, et.al., (2016) said that accounting policies for zakat are totally different from western business policies. Zakat accounting policies must be in accordance with sharia too. Saad, et.al., (2014) also said that the management of zakat fund accounting cannot be separated from Islamic law. Ashraf \& Rauf (2020) found that zakat accounting made by the Waseela Foundation still records simply the receipt and use of zakat funds, even though accounting for nonprofits requires complicated recording and reporting to distinguish from which sources the donations were received and how they were distributed. .

Mohammed, et.al., (2015) said that Islamic financial institutions are aware of the existing AAOIFI accounting standards, which are used as a reference in preparing financial statements. But Islamic financial institutions in Malaysia express their concern regarding the use of AAOIFI standards as a basis for the preparation of financial statements, because many countries in the world have accepted IFRS globally making it difficult for AAOIFI to be accepted. This is in line with Sasan, et.al., (2015) also stating that Islamic accounting has not grown optimally, even though the economy and banking of Islam are growing rapidly. In this case, AAOIFI as an Islamic accounting standard cannot be accepted globally, while the accounting disclosure procedure for Islamic financial institutions including zakat does not yet exist in IFRS.

In Sragen itself, there are seven zakat management organizations registered in the Ministry of Sragen, namely BAZNAS, Religion LASKU, LAZISMU, LAZISNU, LAZ Yatim Mandiri,
Baitul Maal Hidayatullah, and Baitul Misbah. Accountability of zakat management organizations is shown in the financial statements presented, to be able to be legalized as an official organization, OPZ must use a proper accounting system and be ready to be audited by a public accountant. This means that zakat accounting standards are absolutely necessary, because in PSAK 109 zakat accounting aims to regulate the recognition, measurement, presentation, and disclosure of zakat and infaq / alms transactions. This research was conducted as empirical evidence about the application of PSAK 109 in zakat management organizations (OPZ) in Sragen Regency. Based on the description above, this study was conducted in order to find out whether the financial statements of Zakat Management Organizations in Sragen Regency (BAZNAS, case studies LAZISNU, LAZISMU, and LAZKU) are in accordance with PSAK No. 109.

\section{METHOD}

This research is a qualitative research with descriptive method, namely the method carried out by collecting, preparing, and analyzing data so as to get a clear picture of the application of zakat accounting in Zakat Management Organizations Sragen them in BAZNAS, LAZISNU,LAZISMU, and LAZKU Sragen. Sources of data in this study are primary data and secondary data. Primary data obtained directly through interviews with BAZNAS, LAZISNU, LAZISMU, and LAZKU Sragen. While secondary data includes books or documentation relating to the problem, the opinions of experts and reports of research results.

Data collection techniques carried out by: 1) Direct observation, namely by making direct observations regarding the accounting process of zakat and donation 
JASa (Jurnal Akuntansi, Audit dan Sistem Informasi Akuntansi)

Vol. 4 No. 3/ December 2020

ISSN 2550-0732 print / ISSN 2655-8319 online

/ alms in BAZNAS, LAZISNU, LAZISMU, and LAZKU Sragen. This is done to find out firsthand how to apply zakat and infaq / alms accounting. 2) Interview, conducted to obtain information directly about the application of accounting that has been used by BAZNAS, LAZISNU, LAZISMU, and LAZKU Sragen by asking questions to the financial manager or financial staff. 3) Documentation, namely the collection of documents in the form of financial statements. The analysis technique used in this study is a comparative descriptive technique by collecting data on zakat accounting and donation / alms from the research object and then compared with PSAK 109. In this study the authors looked at financial statement data made by BAZNAS, LAZISNU, LAZISMU, and LAZKU Sragen.

The technique used in sampling is purposive sampling technique that is technique as a source of data using certain considerations. This technique is carried out to direct the collection of data in accordance with needs through selection to become a source of data. In this study, before determining the sample, the researcher went to the Office of the Ministry of Religion in Sragen Regency and met with the Head of the Information Division of Islamic Religion, Zakat and Waqf. Then submitted that the Zakat Management Organization in Sragen seven as mentioned above, and recommended to be used as research samples which are BAZNAS, LAZKU,LAZISMU, LAZISNU, and LAZ Yatim Mandiri.

This is based on the collection collected by the OPZ more than Rp. $2,000,000,000$ in a year, while Baitul Maal Hidayatullah and Baitul Misbah collected a new average of Rp. 600,000,000 - Rp. $720,000,000$ a year. Referring to the suggestions from the Information Division of Islamic Religion, Zakat, and Endowments above, the samples taken in this study are BAZNAS, LAZKU, LAZISMU, LAZISNU, and LAZ Yatim Mandiri Sragen Regency. However, after the hospitality friendship to the relevant OPZ, LAZ Yatim Mandiri did not allow research to be carried out due to limited permission from the LAZ Yatim Mandiri Center. So the samples used for the study are BAZNAS, LAZKU, LAZISMU, and LAZISNU Sragen district.

\section{RESULTS AND DISCUSSION} BAZNAS, LAZISNU, LAZISMU, and LAZKU Sragen actually knew of PSAK 109 regarding zakat and infaq / alms accounting for the purpose of standardizing the form of financial statements in each zakat management organization. For LAZISNU Sragen and LAZISMU Sragen, the reporting format has been provided by LAZISNU and LAZISMU in accordance with PSAK 109, but the branch is not yet complete. Whereas the BAZNAS Sragen and LAZKU Sragen in preparing their financial statements still use the simple recording method. The accounting process required by PSAK 109 aims to make uniformity in the preparation of financial statements in each zakat management organization, which includes recognition and measurement, presentation, disclosure, and reporting. The following discusses the analysis of the application of zakat accounting in BAZNAS, LAZISNU, LAZISMU, and LAZKU Sragen with PSAK 109.

BAZNAS Sragen

The accounting treatment of zakat BAZNAS Sragen is not in accordance with PSAK 109. In recognition and measurement it is in accordance with the criteria in PSAK 109 namely zakat funds or infaq / alms funds are recognized when amil received from muzakki, and is recorded in the amount of funds received. Likewise, when channeling funds for the program. However, the recording done by 
JASa (Jurnal Akuntansi, Audit dan Sistem Informasi Akuntansi)

Vol. 4 No. 3/ December 2020

ISSN 2550-0732 print / ISSN 2655-8319 online

BAZNAS is limited to including zakat or infaq / alms without making a journal and ledger. BAZNAS also acknowledges that from the zakat or infaq / alms funds received there are amil rights in them. This is based on the results of an interview with Ms. Dian (financial staff) as the informant "if for policies the percentage of amil funds we take from receiving zakat funds is $12.5 \%$ and $20 \%$ of infaq / alms funds, deck."

Whereas for measurement is the process of determining the value of the receipt of zakat or donation / alms in the form of assets non-cash. The measurement method according to PSAK 109 uses the fair value or as stipulated in the relevant PSAK. Based on the results of interviews, in measuring the receipt of zakat or donation / alms, BAZNAS follows the prevailing market prices at the time. "For determining fair value we use market prices, deck."

The financial statements presented by BAZNAS Sragen are not in accordance with PSAK 109. Whereas in PSAK 109 it is submitted that zakat funds, infaq / alms funds, amil funds, and nonhalal funds are presented separately in the statement of financial position, but the statement of financial position presented by BAZNAS Sragen does not separate zakat funds, infaq / alms funds, amil funds, and non-halal funds, but BAZNAS records them in one name as current fund equity. In the balance sheet there are also assets under management, the assets under management report should be made separately. Amil financial statements in accordance with PSAK 109 in the form of statements of financial position, reports on changes in funds, reports on changes in assets under management, statements of cash flows, and notes to financial statements. But the Sragen BAZNAS only reports on income and expenditure. As stated Dian's mother follows; "Yes, for the report we are separating, but yes the deck

is still in a simple format for income and expenditure reports."

Disclosure in the financial statements aims to provide information to outside parties to assess and evaluate work performance and as a form of accountability of zakat management organizations in managing zakat funds and alms / alms funds. PSAK 109 requires each organization that manages zakat to make disclosures about the activities of the institutions listed in the notes to the financial statements. The notes to the financial statements contain an explanation of the policies and procedures for the distribution of zakat funds, infaq / alms funds, policies regarding the distribution of funds, determination of fair value used when receiving in the form of non-cash assets and non-halal funds, as well as other matters that need to be disclosed. Even though BAZNAS Sragen has information and policies related to management activities, the items required by PSAK 109 are not included and narrated in the notes to the financial statements. The information and policies are only limited by the decision of the Sragen BAZNAS council. "The distribution policy, the percentage of amil funds, program funds and other policies that have been made by the sharia board, we just need to follow and run the deck. The Policy is only internal, deck. "LAZISNU Sragen zakat accounting treatment LAZISNU Sragen is not yet fully in accordance with SFAS 109. In recognition in accordance with the criteria in SFAS 109 that zakat fund or funds donation / charity is recognized when the collector receives from muzakki, and accounted for funds received. Likewise, when channeling funds for the program. Based on the results of an interview with $\mathrm{Mr}$. Haris that after receiving proof of the transaction then the finance department will journalize and make a ledger in accordance with the contract and the 
JASa (Jurnal Akuntansi, Audit dan Sistem Informasi Akuntansi)

Vol. 4 No. 3/ December 2020

ISSN 2550-0732 print / ISSN 2655-8319 online

amount received. LAZISNU also acknowledged that from the zakat or infaq / alms funds received there were amil rights in them. Mr. Haris said that the percentage of amil funds from the receipt of zakat funds was $12.5 \%$ and $20 \%$ of the infaq / alms funds. "As for the percentage of amil funds, $12.5 \%$ is taken from zakat funds and $20 \%$ from donations / donations, ma'am." As for measurements, so far LAZISNU has not taken measurements for the receipt of zakat or donation / alms in the form of non-cash assets. This is because until now LAZISNU has never received donations in the form of non-cash assets. According to Mr. Haris, when someday LAZISNU receives a donation in the form of noncash assets in determining its value, we value it in accordance with the prices prevailing in the market at that time. "Until now we have not received donations in the form of non-cash assets, but when one day we receive them, we will value the donations in accordance with the market price, in accordance with the provisions in PSAK 109, mba." The financial statements presented by LAZISNU Sragen are not yet fully in accordance with PSAK 109. Where in the presentation of financial position reports, LAZISNU presents zakat funds, and infaq / alms funds, amil funds and non-halal funds separately, this is in accordance with the provisions in PSAK 109 LAZISNU prepares financial reports in the form of financial position reports, reports on changes in funds, and reports on sources and uses of funds (cash flow). Where in the source and use report presents the inflows and uses of zakat funds and donations / alms. This report reflects the organization's performance, especially its ability to attract funds in large amounts and types as well as the ability to channel funds quickly to the target, so that the purpose of zakat and infaq / alms is achieved and can be implemented.
Broadly speaking, the financial statements prepared by LAZISNU are not in accordance with PSAK 109, because in PSAK 109 the complete financial statements consist of statements of financial position, statements of changes in funds, statements of changes in assets under management, statements of cash flows, and notes to financial statements. Whereas LAZISNU did not make reports on assets under management because LAZISNU did not have its own building, and LAZISNU also did not make notes on the financial statements. In addition, LAZISNU Sragen also has not conducted audits by public accountants.

"Yes, for the report we have separated, you can see it on the balance sheet. In addition to the balance sheet, the financial statements that we make report changes in funds, and reports on the source and use of funds, mba. "

PSAK 109 requires each organization that manages zakat to make disclosures about the activities of the institutions listed in the notes to the financial statements. The notes to the financial statements contain an explanation of the policies and procedures for channeling zakat funds, infaq / alms funds, policies regarding the distribution of funds, determining the fair value used if receiving in the form of non-cash assets and non-halal funds, as well as other matters that need to be disclosed. Based on information from Mr. Haris said that the policies had been made, only limited to internal not to be published. Even though LAZISNU Sragen has information and policies related to management activities, the things required by PSAK 109 are not included and narrated in the notes to the financial statements, this cannot be said to be complete financial statements in accordance with PSAK 109.

"If for distribution policies, the percentage of amil funds and our policies is followed by the sharia council, but we 
JASa (Jurnal Akuntansi, Audit dan Sistem Informasi Akuntansi)

Vol. 4 No. 3/ December 2020

ISSN 2550-0732 print / ISSN 2655-8319 online

haven't narrated the policy in the notes to the financial statements, only the notes from the sharia council for us to manage.

$"$

\section{LAZISMU Sragen LAZISMU Sragen accounting treatment was in} accordance with PSAK 109. In recognition, it was in accordance with the criteria in PSAK 109, namely zakat funds or donations or alms funds when the amil received from muzakki, and recorded the amount received. Likewise, when channeling funds for the program. Mrs. Ifah said that after receiving proof of the transaction then the staff of the finance department would journalize and make a ledger in accordance with the contract and the amount received. LAZISMU also acknowledges that there is amil part of zakat funds or infaq / alms funds, the percentage is $12.5 \%$ of zakat funds and $20 \%$ of infaq / alms funds. The following is delivered by Mrs. Ifah; "For maximum amil funds we will get $12.5 \%$ of zakat funds, and $20 \%$ of deck infaq funds" For measurements, so far LAZISMU has not taken measurements for the receipt of zakat or infaq / alms in the form of noncash assets. Based on an interview with Ms. Ifah, when LAZISMU received donations in the form of non-cash assets such as rice, the financial staff section recorded it as inventory or deposited and recorded separately. After recording it as inventory or for safekeeping, the lapse of one or two days for safekeeping is distributed to mustahiq in need.

"During this time, when we receive donations in the form of goods, we record them as inventory or left for safekeeping. And when we receive donations in the form of goods as soon as possible we also distribute the deck. "

The financial statements presented by LAZISMU Sragen are in accordance with PSAK 109. Wherein in the presentation of financial position reports, LAZISMU

presents zakat funds, infaq / alms funds, amil funds, and non-halal funds in a fixed amount. The financial statements prepared by LAZISMU consist of statements of financial position, statement of changes in funds, statement of changes in assets under management, statement of cash flows and notes to financial statements. LAZISMU Sragen has also conducted a financial audit, this audit was carried out by the Public Accountant Office appointed by the Central LAZISMU. But due to agency data privacy, only reports of changes in funds are permitted to be attached to this study. "Yes, we have separated the report, because we also report it to the central government and the center wants to be in accordance with PSAK 109 deck. In addition to the central LAZISMU office, we at the branch office are also audited by the KAP appointed by the deck center." In PSAK 109 requires each organization that manages zakat to make disclosures about the activities of the institutions listed in the notes to the financial statements. The notes to the financial statements contain an explanation of the policies and procedures for channeling zakat funds, infaq / alms funds, policies regarding the distribution of funds, determining the fair value used if receiving in the form of non-cash assets and non-halal funds, as well as other matters that need to be disclosed. Based on information from Mrs. Ifah, those policies have been LAZISMU Sragen included and narrated in the notes to the financial statements. "Yes, we have attached all the policies related to institutions, distribution policies, amil fund policies and other policies, thank God, in the notes to the financial statements, deck." LAZKU Sragen LAZKU Sragen accounting treatment is not in accordance with PSAK 109. In recognition and measurement it is in accordance with the criteria in PSAK 109, namely zakat funds or infaq / alms funds are recognized when 
JASa (Jurnal Akuntansi, Audit dan Sistem Informasi Akuntansi)

Vol. 4 No. 3/ December 2020

ISSN 2550-0732 print / ISSN 2655-8319 online

amil received from muzakki, and is recorded in the amount of funds received. Likewise, when channeling funds for the program. But LAZKU's records were only limited to including zakat or infaq / alms funds without journalizing and making its ledgers. LAZKU also recognizes that from the zakat funds or donations / alms funds received amil rights in them. This is based on the results of interviews with Ms. Umi (manager) as the informant said that the percentage of amil funds from the receipt of zakat funds amounted to $12.5 \%$ and $30 \%$ of the infaq / alms fund. For measurements when receiving donations in the form of non-cash assets, the method used at fair value follows the prevailing market price. The following quote was delivered by Umi's mother;

"As for the policy in taking amil percentage funds, we follow the direction of our council, ok. We will get $12.5 \%$ of zakat funds and $30 \%$ from donations / donations, deck. " The financial statements presented by LAZKU Sragen are not in accordance with PSAK 109. Wherein in PSAK 109 it is stated that zakat funds, infaq / alms funds, amil funds, and non-halal funds are presented separately in the statement of financial position, but LAZKU Sragen does not make financial position reports. Amil's financial statements prepared by LAZKU also do not comply with PSAK 109. In PSAK 109 the amil financial statements consist of statements of financial position, changes in funds, reports on changes in assets under management, statements of cash flows, and notes to financial statements. But LAZKU Sragen only made reports on the receipt and use of funds. "Yes, for the report, we separate it according to the contract, deck. But for the format, our financial statements are still very simple, only limited to reports on the receipt and use of funds, deck. " Disclosures in the financial statements in accordance with PSAK 109 contain policies and information on the activities of the institutions which are listed and narrated in the notes to the financial statements. LAZKU Sragen does not make notes on financial statements. "Disclosures in the financial statements have not made LAZKU deck." Zakat management organizations cannot underestimate the accountability of zakat funds. Because accountability is a form of amil accountability to mustahiq in the form of presenting, reporting, and disclosing all activities and activities of collecting zakat funds and infaq / alms funds. Based on research results at BAZNAS, LAZISNU, and LAZKU Sragen not fully in accordance with PSAK 109. While for LAZISMU Sragen is in accordance with PSAK 109.accordance with PSAK 109.

Based on the accounting treatment of zakat applied at BAZNAS, LAZISNU, LAZISMU, and LAZKU Sragen in recognition and disclosure is in with PSAK 109. This can be seen based on the percentage of funds received for amil, which is a maximum of $12.5 \%$ or $1 / 8$ of the receipt of zakat. This distribution is adjusted to the rules contained in the At Taubah verse verse 60 that there are 8 groups who are entitled to receive zakat. And for the receipt of funds from infaq / alms each opz determines a different percentage. BAZNAS, LAZISMU, and LAZISNU Sragen adopted a percentage policy for amil funds of $20 \%$ while for LAZKU the percentage of amil funds was $30 \%$. In the implementation of presentation and reporting made by the management organization zakat in Sragen, which in this study sample is limited to BAZNAS, LAZISNU,LAZISMU, and LAZKU Sragen. In accounting treatment BAZNAS and LAZKU make a simple recording report in the form of income (revenue) and expenditure (usage) reports. While LAZISNU Sragen only reports on changes in funds, reports on financial position and reports on 
JASa (Jurnal Akuntansi, Audit dan Sistem Informasi Akuntansi)

Vol. 4 No. 3/ December 2020

ISSN 2550-0732 print / ISSN 2655-8319 online

sources and uses of funds. And only LAZISMU Sragen complies with PSAK 109. Reports made by LAZISMU consist of statements of financial position, reports on changes in funds, reports on changes in assets under management, statements of cash flows, and notes to financial statements.

\section{CONCLUSION}

This research was conducted with the aim of finding out whether the application of zakat accounting in zakat management organizations in Sragen regency was in accordance with PSAK 109 or not. This study used a sample of 4 zakat management organizations registered at the office of the religious ministry in Sragen regency namely BAZNAS, LAZISNU, LAZISMU, and LAZKU Sragen. The first conclusions obtained in the preparation of BAZNAS and financial statements LAZKU have not applied PSAK 109, LAZISNU is not yet fully in accordance with PSAK 109 and only LAZISMU Sragen whose financial statements are in accordance with PSAK 109. Financial responsibility presented by BAZNAS and LAZKU is still limited to the income report (receipt). and expenditure (use) of funds. Meanwhile LAZISNU and LAZISMU in principle are in accordance with PSAK 109, only for LAZISNU there are still shortcomings namely not making reports on changes in assets managed and notes on financial statements. Padahal pada PSAK 109 laporan keuangan yang lengkap terdiri dari : laporan posisi keuangan, laporan perubahan dana, laporan perubahan aset kelolaan, laporan arus kas dan catatan atas laporan keuangan. Kedua laporan keuangan yang disajikan oleh BAZNAS dan LAZKU masih belum informatif. Hal ini dikarenakan perlakuan akuntansi zakat yang belum sesuai dengan PSAK 109. Sedangkan laporan keuangan yang disajikan oleh LAZISNU dan LAZISMU

sudah informatif. LAZISNU dan LAZISMU merincikan penerimaan dana dari muzakki dan penyaluran dana untuk mustahik. Selain itu LAZISMU secara berkala diaudit oleh auditor independen dengan opini wajar tanpa pengecualian.

Penelitian ini berfokus pada penerapan PSAK 109 tentang akuntansi zakat pada organisasi pengelola zakat di kabupaten Sragen. Keterbatasan yang ada dalam penelitian adalah terbatasnya dalam pengumpulan data. Hasil pengumpulan data yang didapat oleh peneliti belum maksimal, hal ini dikarenakan adanya privasi dan kebijakan organisasi pengelola zakat yang bersangkutan terkait laporan keuangannya. Saran bagi peneliti selanjutnya sebaiknya menambah sampel penelitian tidak hanya organisasi pengelola zakat di kabupaten Sragen saja tapi bisa lebih meluas lagi.

\section{REFERENCE}

Ahmed, EA (2016). Zakat and Accounting Valuation Model. Journal of Reviews on Global Economics, 16-24.

Angraeni, EP (2016). Penerapan Akuntansi Zakat dan Infak/Sedekah Berdasarkan PSAK 109 Pada Badan Amil Zakat Kota Bitung. Jurnal EMBA, Vol.4 No.4 Hal. 1191-1199.

Arief, SW (2017). Analisis Penerapan PSAK No. 109 Tentang Akuntansi Zakat, Infaq/Sedekah Pada Badan Amil Zakat Nasional Kota Manado. Jurnal Riset Akuntansi Going Concern, 12(1), 98-107.
Ascarya
(2014).
Sustainable
Conventional and Islamic
Microfinance Models for Micro
Enterprises. ISRA International Colloquium for Islamic Finance. Kuala Lumpur. 
JASa (Jurnal Akuntansi, Audit dan Sistem Informasi Akuntansi)

Vol. 4 No. 3/ December 2020

ISSN 2550-0732 print / ISSN 2655-8319 online

Ashraf, J. \&. (2020). Waseela Foundation: Accounting for Zakat. Asian Journal of Management Cases, S55-S60.

Asrori, P. \&. (2015). Implementasi PSAK 109 Pada Organisasi Pengelola Zakat dan Infak/Sedekah di Kota Semarang. Accounting Analysis Journal, 4 (1).

Bashir, M. \&. (2012). Analysis of Zakat Management in Brunei Darussalam. International Journal of Management Studies, 75-102.

Beik, I. (2015). Towards International Standardization of Zakat System. Fiqh Zakat International Conferences, (hal. 3-17).

Bremer, J. (2013). Zakat and Economic Justice: Emerging International Models and Their Relevance for Egypt. Third Annual Conference on Arab Philanthropy and Civic Engagement, (hal. 51-74). Tunis.

Budiarti, AM (2017). Evaluasi Penerapan PSAK 109 Tentang Pelaporan Keuangan Akuntansi Zakat, Infaq/ Shadaqah Pada BAZNAS Kota Yogyakarta. Jurnal Akuntansi dan Sistem Teknologi Informasi, Vol. 13 No. $1 \mathrm{Hal}:$ 41-47.

Doktoralina, C. \&. (2018). Zakat Accounting Information System in Private Higher Education. European Research Studies Journal, pp. 265-275.

Hamat, AE (2017). Shares Zakah A ccounting in Malaysia: Fatawa, Manual and Practices. International Journal of Academic Research in Business and Social Sciences, Vol. 7 No. 2.

Hamat, Z. (2014). Sustainable Zakat Accounting in Malaysia: An Analysis. Mediterranean Journal of Social Sciences, Vol. 5 No. 19.

Hamid, A. \&. (2019). Strengthening Role of World Zakt Form: Lembaga Zakat Selangor (MAIS)
Viewpoints. Center of Islamic Philanthropy and Social Finance, 112-118.

Harianto, S. (2016). Accounting For Zakat on Income Critical Study Based on Government Regulation (Case Study in Aceh Province of Indonesia). International Journal of Business, Accounting and Management, Vol 1 Issue 3, Pp: 47-52.

Hidayat, SR (2018). Implementasi Pernyataan Standar Akuntansi Keuangan 109 Pada Rumah Yatim Arrohman : Identifikasi Faktor Pendukung. Jurnal Akuntansi Terapan Indonesia, Vol. 1 No. 1 Hal : 17-26.

Ikatan Akuntansi Indonesia. (2011). Pernyataan Standar Akuntansi Keuangan No. 109 Akuntansi Zakat dan Infak/ Sedekah. Jakarta: IAI.

Kristin, A. \&. (2011). Penerapan Akuntansi Zakat Pada Lembaga Amil Zakat ( Studi Pada LAZ DPU DT Cabang Semarang). VALUE ADDED, Vol. 7 No. 2.

Latief, N. (2019). Accounting for Zakat and Infaq (Sadaqah) at Badan Amil Zakat Nasional (BAZNAS) In North Sulawesi, Indonesia. International Journal of Accounting \& Finance in Asia Pacific (IJAFAP), Vol. 2 No. 2.

Marhaini, M. \&. (2018). Implementation PSAK 109 About Accounting of Zakat at BAZNAS of West Nusa Tenggara Province. International Journal of Economics, Commerce and Management, 644-653.

Mayangsari, IN (2019). Analisis Perlakuan Akuntansi Zakat pada Lembaga Amil Zakat Baitul Maal Hidayatullah (BMH) Kabupaten Bondowoso. International Journal of Science and Business, Vol 3 No. 1, pp. 28-35. 
JASa (Jurnal Akuntansi, Audit dan Sistem Informasi Akuntansi)

Vol. 4 No. 3/ December 2020

ISSN 2550-0732 print / ISSN 2655-8319 online

Mohammed, NF (2015). The Influence of AAOIFI Accounting Standards in Reporting Islamic Financial Institutions in Malaysia. Procedia Economics and Finance, 418-424.

Nugraha, S. (2018). Implementation of Zakat Accounting in Amil Zakat Institute (LAZ) in Jember. International Journal of New Technology and Research, 52-57.

Accounting. Journal of Economic Essays, 109-133.

Shahnaz, S. (2015). Penerapan PSAK No. 109 Tentang Pelaporan Keuangan Akuntansi Zakat, Infaq/Sedekah Pada Badan Amil Zakat Provinsi Sulawesi Utara. Jurnal EMBA, Vol. 3 No. 4, Hal: 315-324.

Pamuncak, MP (2018). IFRS Based Zakat Reporting: Adoption Rational Western Method Into Institutional Accountability. Journal of Islamic Economics and Business, Vol. 3 No. I, Page: 17-34.

Pertiwi, RK (2015). Analisis Penerapan Akuntansi Dana Zakat dan Infak/Sedekah Pada Lembaga Amil Zakat Infaq, dan Shadaqah Muhammadiyah (LAZISMU) Kabupaten Malang. Jurnal Reviu Akuntansi dan Keuangan, Vol.5 No.2, Pp 751-758.

Ritonga, P. (2017). Analisis Akuntansi Zakat Berdasarkan PSAK No. 109 Pada Badan Amil Zakat Nasional (BAZNAS) Sumatera Utara. KITABAH, Vol 1 No. 1.

Saad, R. \&. (2014). Determinants of Zakah (Islamic TAX) Compliance Behavior. Journal of Islamic Accounting and Business Research, Vol. 5 No. 2, pp: 182193.

Saputro, EA (2018). Analisis Penerapan PSAK 109 Pada Lembaga Amil Zakat (Studi Kasus Pada LAZIS Sabilillah Kota Malang). Jurnal Ilmiah Riset Akuntansi, Vol. 7 No.4.

Sarea, A. (2013). Accounting Treatment of Zakah: Additional Evidence from AAOIFI. Journal of Islamic Banking and Finance, Vol. 1 No. 1.

Sasan, MR (2015). The Study of Presenting New Financial Statements Within Islamic 